https://jurnal.unigal.ac.id/index.php/jall/index

JALL (Journal of Applied Linguistics and Literacy), ISSN 2598-8530, September, Vol. 4 No. 2, 2020

\begin{tabular}{|ccc|}
\hline Received & Accepted & Published \\
\hline August 2020 & September 2020 & September 2020 \\
\hline
\end{tabular}

\title{
Intercultural Translation: The Case of Translating Figurative Aspects of English into Indonesian
}

\author{
Suhendra Yusuf \\ suhendrayusuf@gmail.com \\ Universitas Islam Nusantara Bandung
}

\begin{abstract}
Figurative is used to enlarge the effect of the statement. This figurative language is usually the style of language used by the author to express something unusual disclosure, that uses comparison, imagery, affirmation, sarcasm, contention, or something engagement with other things that attract the attention of readers. Figurative language used by the author with a view to turn the way of disclosure and the atmosphere so as to be meaningful discourse. Figurative language translation can also be incorporated into the literary translation, the translation of works of fiction, poetry, or drama, because the figurative language used by the author, poet, or playwright to produce work that is more imaginative. There are some reason why people use figurative language (1) Language figurative able to produce imaginative fun; (2) The figurative language is a way to generate additional images in the poem and make poetry more enjoyable read; (3) The figurative language is a way to add intensity; and (4) figurative language is a way to concentrate the meaning that would be submitted and how to deliver something that a lot and spacious with a brief language.
\end{abstract}

Keywords: intercultural translation, figurative language

\section{INTRODUCTION}

Figurative language is also called figure of speech, which is divided into a comparison figure of speech, figure of speech assertion, innuendo figure of speech, and a figure of speech contention. Which belong to the comparative figure of speech, among others, simile, metaphor, personification, metonymy, euphemism, hyperbole, or synesthesia. The figure of speech such as redundancy, repetition, parallelism, and belong to the rhetorical figure of speech affirmation. Majas satire among others, is irony, sarcasm, and cynicism. Majas contention include, for example paradox and antithesis.

Simile is a figure of speech that compares something with something else explicitly using the words: like, like, like, such as, suppose, or the like; eg He moves 
like lightning. Metaphor, as well simile, is a figure of speech comparing things with other things based on similarities in terms of the nature, circumstances, or deed. Metaphor is a style of expression by using another word or phrase to another object or concept is based on figurative or equation; for example the horizon for prefigured the human foot. Personification is a comparative figure of speech to describe something (objects) that death seems to be alive; for example, in the sentence Clouds return. The metonymy is the use of the name for another object or being associated attributes; eg Si Whisker for someone who has a mustache. Euphemism is the use of the word or other forms to avoid any form of prohibition, taboo, or something that is considered rude; for example the phrase backwards to replace the word urinate or defecate. Hyperbole is the force disclosure of exaggeration, for example uangkapan We deliver to thousands of millions of thanks and apology. And synesthesia is the style of the disclosure by comparing something with specific objects or concepts related to certain senses; for example in the expression Crowded true color of the clothes he wore. comparing clothes with lively sound.

Redundancy is a figure of speech affirmation by using the word or phrase that is excessive than necessary, for example in the expression We should and must follow this rule. Repetition is the repetition of words or phrases several times to give a certain effect or to give emphasis on what is proposed, for example, in the sentence We are a free nation! We are a sovereign nation! We are powerful! Parallelism is the use of language that is repeated, either in sound, word, sentence structure, or meaning, for example, in the phrase We are one, we are united, we missed out on the mahasatu. Or a rhetorical question is rhetorical style of the disclosure in the form of actual question does not require an answer, such as Do you want a better life? (Kridalaksana, 1993).

Stylistic irony is a statement about something by throwing it into something else. Dictionary of Terms Literature says that irony is a figure of speech that contains a statement that contains a conflict between the said and the reality is that the mismatch between expectations and realities facing (Zaidan et al, 1994: 90), for example the statement: We do not have a concept to overcome flood responded with irony the following: The concept is: We have to be strong! (Marsudi, 2003). Cynicism is a more rugged style of irony, and sarcasm is the language style satire rudest to use words that are not polite.

The paradox is the kind of contradiction that figure of speech using words that means the opposite when the real intention is not, due to different object; eg The rich man died in the famine. The antithesis is a figure of speech opposition in opposing the use 
of wording for emphasis and attention; eg From head to toe, no escape from his observations.

\section{DISCUSSION}

As mentioned above, this figurative language related to the culture so that it can be said that the translation of figurative language related to cultural translation. In cultural translation, the message in the source language culture transformed into a message in the target language culture. Therefore, the translator should have good ability in culture both languages. This is the main obstacle in the figurative language translation.

The first problem with regard to how to find a common ground in the translation equivalent for figurative meaning. For example, the following sentence using a figure of speech simile.

- Your friend is as sly as a fox.

If translated literally, this sentence will be

- Your friend is as wily wolves.

- Your friend is clever like a fox.

In British culture, as reflected in the stories people, wolves or foxes often described as an animal clever and smart in playing outwit other animals or even humans. On the contrary, in our culture, the wolf is often portrayed as evil beasts and wild life in the forest, far away from human life. In the story of our children, the animals are often depicted clever is clever individual. Thus, if the context of our culture, the translation of the sentence is:

- Your friend is clever like a deer.

- Your friend is as wily deer.

Similarly, expression of the shirt is as white as snow if translated would be the following sentence.

- This clothing white as snow.

- These clothes as white clouds.

- Clothing is as white as cotton.

For users living language in four seasons, the expanse of white snow can be a comparison to other things that are white, while those of us who do not know the winter, on the part of our society, chunks of clouds in the sky commonly used as a comparison for the color white. For some farmers in rural communities, the white color is often associated to color cotton. Thus, the phrase should be translated into "... as white clouds." Or "... as white as cotton." 
In translation this simile, there are three things that must be considered, namely (1) the topic, (2) images (image), and (3) the point of similarity in the comparison. According to Larson (1984), the translator's ability to identify three aspects of the topic, image, and point of similarity in figurative meaning analysis can help solve the problem of translation of this figurative language.

Despite the decisive point of similarity in this simile figure of speech is relatively easy, there are other things that also need the attention of a translator. This relates to the difference of meaning far enough between the source language and the target language. For example, the phrase be as slippery as an eel has imagery and point of similarity is identical in Indonesian, the 'slippery as an eel'. But when examined deeper meaning, there are differences between the two cultures in understanding the 'slippery as an eel' is. According http://idioms.thefreedictionary.com/, a slippery as eels are people who can not be trusted. ( "... Someone who is as slippery as an eel can not be trusted; devious and untrustworthy, but impossible to catch"), as in the expression You'd be mad to go into business with him. He's as slippery as an eel. Or in the words of The con artist was as slippery as an eel. Although he defrauded many people, he never went to prison. (McGrawHill Dictionary of American Idioms and Phrasal Verbs, 2002).

In our culture, people are slippery like an eel is not up to the assessment that 'deceptive, untrustworthy' although no negative traits. For human nature is to be believed this, we usually use the expression 'like a snake'. Thus, if the context is human nature relating to dishonesty and mistrust, then matching the right translation is "... like a snake," for example, the translation above: "You'd be crazy to do business with. He was like a snake. "

The English expression which roughly have the same meaning as above is a snake in the grass, which means "a sneaky and despised person." For example in the sentence How could I ever have trusted that snake in the grass? John is such a snake in the grass. Or a snake in the grass also can mean "people who pretend well, but behind even harm" as in the phrase It's upsetting to learn that someone you once Viewed as a good colleague is in fact a snake in the grass. The second problem with regard to how to find images or image (image) is right in the target language culture. As well as the above simile, the metaphor of translation, the translation process can become more difficult mainly because the relationship between the subject and the images are usually implicit. British culture eg animal imaging horses, oxen, and lions as pets are very strong, as reflected in the following expression.

- Get Linda to help you push it; she's as strong as a horse. 
- The athlete was strong as an ox; he could lift his own weight with just one hand.

- The football player was strong as a lion.

Meanwhile, in our culture, the animals were imaged very strong it is usually an elephant or a bull; so that both the animal metaphor is often associated with the power as well as horses, cattle, and lions in British culture. The images or image is not only related to what can be seen with the eye, but also what is heard, tasted, touched, kissed, think, move, or felt. Images that may cause the reader seemed to see, hear and feel for yourself what is experienced by the author. Authors typically use images that are not separately but secarqa together to nurture the idea to be conveyed.

Translators should do first research paper regarding the images that do the authors in the works to be translated. For example, there are authors who prefer to use flora and fauna as a metaphor, such as wine and milk as a symbol of fertility; vine has budded, "" grape blossoms are open, "" pomegranates are in bloom "all showed images of eroticism (Bloch \& Bloch, 2009). Based on the answers to the above questions, the translator will get a kind of 'road map' use of imagery in that essay. map this imagery will greatly assist translators in finding common ground and find a translation equivalent for the images in question.

Some examples of the use of figurative language below interpreter requires special attention in handling it. If translated literally, the sentences would be very strange and unreasonable, for example into the following sentences.

Table 1. Comparasion on different ways of translation

\begin{tabular}{|l|l|}
\hline $\begin{array}{l}\text { I laughed my head off at } \\
\text { Mary's joke. }\end{array}$ & I laughed my head on prank Mary. \\
\hline Jojon's new car is the apple of his eye & $\begin{array}{l}\text { The new car Jojon is the apple of } \\
\text { his eyes. }\end{array}$ \\
\hline $\begin{array}{l}\text { This young lady had a skeleton in } \\
\text { the closet. }\end{array}$ & $\begin{array}{l}\text { This young woman saves skeletons } \\
\text { in the closet. }\end{array}$ \\
\hline Old Tom is stone dead and in the ground. & $\begin{array}{l}\text { Sir Tom and the old stone dead on } \\
\text { the ground. }\end{array}$ \\
\hline We spent the weekend in the Big Apple & $\begin{array}{l}\text { We spent the weekend in the Big } \\
\text { Apple. }\end{array}$ \\
\hline
\end{tabular}


The metaphor are certainly not translated but replaced with metaphors that are known in the Indonesian language. For example the expression below

Table 2. Metaphor Translation

\begin{tabular}{|l|l|}
\hline Expression & Meaning \\
\hline Laugh my head off & $\begin{array}{l}\text { laugh out loud } \\
\text { laughing until the head going to explode }\end{array}$ \\
\hline the apple of his eye & beloved goods \\
\hline $\begin{array}{l}\text { to have a skeleton in the } \\
\text { closet }\end{array}$ & keep secret embarrassing \\
\hline stone dead & $\begin{array}{l}\text { Dead } \\
\text { Motionless }\end{array}$ \\
\hline
\end{tabular}

Some of the images in the above expression it has a point of similarity between English and Indonesian culture though a translator must remain cautious in finding a match. But most metaphorical expression is indeed bound by cultural origin. The following example also shows the differences between cultures rather far in doing comparison metaforisnya (McGraw-Hill Dictionary of American Idioms and Phrasal Verbs, 2002). From the Table, literally, the sentences on the left side can be translated into the sentences on the right side

Table 3. Literal Translation

\begin{tabular}{|l|l|}
\hline $\begin{array}{l}\text { If you do not get a good look at the } \\
\text { engine of a used car before you buy } \\
\text { it, you'll wind up buying a pig in a } \\
\text { poke. }\end{array}$ & $\begin{array}{l}\text { If you do not check in with either } \\
\text { engine used car you want to buy, you } \\
\text { are like buying a pig in a poke.I }\end{array}$ \\
\hline $\begin{array}{l}\text { I just took the salesman's word that } \\
\text { this camera worked. I guess I bought } \\
\text { a pig in a poke. }\end{array}$ & $\begin{array}{l}\text { I believe only what the seller that the } \\
\text { camera is still good. I guess I buy a } \\
\text { pig in a poke. }\end{array}$ \\
\hline
\end{tabular}

Third problem with regard to the translation of idiomatic expressions, which is a group of words whose meaning can not be found on the meanings of words element. According to Richards (1992: 172) idiom is a phrase that serves as a single unit and its meaning can not be broken. Newmark (1988: 47) adds that the idiomatic translation aims to reproduce the message text in the source language to the target language text 
expression more natural and familiar. Crystal (1985: 152) states that the idiom or idiomatic expression is a limited set of words semantically and syntactically, so only function as a single unit.

Table 4. Idiomatic Equivalent Translation

\begin{tabular}{|l|l|}
\hline Excuse me & Literal Meaning: Forgive me \\
& Idiomatic equivalent: \\
& Excuse me \\
& 'I'm sorry, what do you mean \\
& I'm sorry, can I ask?' \\
& I'm sorry to interrupt \\
\hline Thank you & Literal Meaning: You're welcome \\
& Idiomatic equivalent: \\
& Please, do not mention it \\
& Not at all \\
& It was a pleasure \\
& Forget it \\
\hline
\end{tabular}

Larson (1989) says that in the translation of the idiom translator should use the natural form in the target language text, according to the grammatical constructions and lexical choice. Translation truly idiomatic does not seem like the translation, but rather as a direct result of the original author's writings.

Thus, the translation of the idiom can not be done based on the words contained in it. If dogfood can be translated into Indonesian with translations matching dog food, and doggy with a puppy or small dog then dogfight does not necessarily mean dog fights or wrestling a dog, for example. Equivalent translation of dog-fight according to the EnglishIndonesian dictionary Echols and Shadily essay is:

(1) The fight is fierce;

(2) battle between the best hunter chase chasing each other.

Especially for translation from English into Indonesian as above, the author of expression Indonesian-English Dictionary (1998) says that the English language can be considered as an idiomatic language in which are contained the phrase that can only be used in certain contexts. Therefore, to get the 'equivalent translation' of these idioms, the translator should always use the idiom dictionary idiom so precise and natural counterpart.

Other expressions which often cause problems in translation, is also closely related to the idiom and metaphor are proverbs. Big Indonesian Dictionary (2005) 
stated that the proverb is a group of words or sentences fixed structure, usually an analogy specific purpose or brief phrase or sentence solid, unbiased comparisons, parables, advice, life principles or rules of behavior. This maxim certainly not translated but homologize who had the same phrase in the target language proverbs. If not found its equivalent, the descriptive translation can be done by describing the intent of the proverb.

Proverb An apple a day keeps the doctor away, for example, in the phrase of Grandma always fed us lots of apples when we visited her. She Believed that an apple a day keeps the doctor away means that eating an apple a day keeps us from all kinds of diseases. This expression is specific language that is not found in Indonesian counterpart that there is no equal in Indonesian proverb. Other proverbs, such as the Better be the head of a dog than the tail of a lion, easy to understand but hard to find meaning in Indonesian counterpart.

As with the following maxim-maxim that we can find 'equivalent' in Indonesian.

1. A bird in the hand is worth two in the bush Expect high- flying bird, pigeon in hand is released

2. The course of true love never did run smooth the course of true love is full of thorns

3. The damage is done Rice has become porridge

4. The dogs bark, but the elephant goes on Dogs barking, the caravan passes

5 . The customer is always right buyer is king

Another problem in translation is the use of a euphemism, that disclosure of the words that are considered taboo or perceived rough with other words deemed more appropriate or more subtle (Frye, 1985). Wikipedia defines euphemism as a replacement expressions deemed too offensive, or make people say or who hears feel uncomfortable, with an expression that was more refined. In euphemisms, words that are used is not literal, but turns into a metaphor, so that the translation becomes like the translation of metaphorical expression as described above. In politics and industry, euphemisms used to conceal something unpalatable parties involved and is intended to build a positive image of political figures, parties institution, or company. In this case, this euphemism commonly known as dou $\neg$ blespeak - or double- talk.

There was some kind of euphemism, among other things, a euphemism to replace the words that are considered taboo in a given culture, a euphemism to describe the physical state, a euphemism in religion and everyday life, a euphemism for death or 
murder, or in modern life, as in political and communications industries above. Some examples of euphemisms in English can be seen below.

1. mentally challenged stupid, dumb

2. physically challenged handicapped

3. The penalty fee

4. The big, fluffy, "thick-boned", full-figured or heavy-set fat; obesity

5. lethal injection execution by injection

\section{CONCLUSION}

From the discussion about figurative language translation above, while it can be concluded that the translation of similes, metaphors, idioms, proverbs, or euphemism, not like the translation in general. Translators must be very clever to find the 'equivalent' of the source language expression with the intent and purpose similar disclosures in the target language. Translators also should pay attention to what purpose does the translation of this and who will read this translation, in accordance with the concept of needs analysis in translation (needs analysis) to determine the purpose of the translation, and the concept of audience design to determine who will read the translation, as will be discussed briefly on the next learning activities.

The influence of culture in the use of figurative language is huge. This is due to the comparison, parable, disagreement, or engagement a phrase with its incomparable objects which are within the scope of culture author. Therefore, figurative language translation can be incorporated into intercultural translation, so translators must master not only the culture of the target language but also the culture of the source language.

Figurative language is also called figure of speech, which is divided into a comparison figure of speech, figure of speech assertion, innuendo figure of speech, and a figure of speech contention. In this module discussed comparative example translation figure of speech, among other things, similes, metaphors, euphemisms, and proverbs. In figurative language translation, the translator is required to have good ability in culture both languages.

\section{REFERENCES}

Baker, Mona (Ed.) (1998). Routlegde Encyclopedia of Translation Studies. London: TJ International Ltd.

Baker, Mona. (1992). In Other Words. New York: Routledge. 
Bell, Roger T. (1991). Translation and Translating: Theory and Practice. England: Longman Group UK Ltd.

Bloch and Bloch commentary on Solomon on Sex by Dallow. (2009). Available in www.wsu.edu.

Budick, Sanford and Wolfgang Iser. (1996). The translatability of Cultures. USA: Stanford University Press.

Cambridge Idioms Dictionary, 2nd ed. (2006). London: Cambridge University Press.

Cameron, L. (2003). Metaphor in Educational Discourse, MPG Books Ltd, London, 2003.

Catford, J.C. (1974). A Linguistic Theory of Translation. London: Oxford University Press.

Chesterman, Andrew (1997). Memes of Translation.The Spread of Ideas in Translation Theory .Amsterdam ad Philadelphia: John Benjamins.

Dirk Delabastita et.al. (2006). Functional Approaches to Culture and Translation. Selected papers by José Lambert. Amsterdam / Philadelphia: John Benjamins Publishing Company.

Duff, Alan. (1981). The Third Language: Recurrent Problems of Translation into English. England: Pergamon Press.

Echols, John M. and Hassan Shadily._(1994). Indonesian English dictionary. Jakarta: PT. Gramedia Pustaka Utama. (1996). English-Indonesian dictionary. Jakarta: PT. Gramedia Pustaka Utama.

Gentzler, Edwin (1993). Contemporary Translation Theories. London and New York: Routledge.

Gibbs R.W. \& Steen J.G. (1997). Metaphor in Cognitive Linguistics, Amsterdam

Hatim, Basil and Ian Mason. (1997). The Translator as Communicator. London: Routledge.

Hatim, Basil. (2001) .Teaching and Researching Translation. London: Pearson Education Ltd.

Hermans, Theo (1999). Translation in systems: Descriptive and System-oriented Approaches Explained.Manchester: St.Jerome.

Hervey, Sándor and Ian Higgins. (1992). Thinking Translation. New York: Routledge. 
Hoed, Benny H. (2006). Translation and Culture. Jakarta: Pustaka Jaya.

Hoed, Benny H., S. Tresnati Solichin, and Rochayah M. (1993). Basic Knowledge On Translation. Jakarta: FSUI Translation Center.

Hornby, Mary Snell. (1995). Translation Studies. An Integrated Approach. Amsterdam: Jon Benjamin Publishing Co.

Ian Mason. (2000). "Audience Design in Translating." Translator 6/1.

Kenney, William. (1996). How to Analyze Fiction. USA: Simon \& Schuster Inc.

Kridalaksana, Harimurti. (1993). Linguistics dictionary. Jakarta: PT. Gramedia Pustaka Utama.

Lakoff, G \& Johnson, M. (1980). Metaphors We Live By. Chicago: The University of Chicago

Larson, Mildred L. (1989). Meaning-Based Translation, A Guide to Crosslanguage Equivalence. Tr. Kencanawati Taniran. Jakarta: Arcan.

Larson, Mildred. (1984). Meaning-Based Translation. A Guide to Cross Language Equivalence. Lanham. University Press of America.

Lefevere, Andre (1992). Translation, Rewriting, and the manipulation of literary fame. London: Routledge.

Lefevere, Andre (1998). "Translation Practice (s) and the Circulation of Cultural Capital. Some Aeneids in English." In Susan Bassnett ed. Constructing Cultures: Essays on Literary Translation. Clevedon: Multilingual Matters.

Lefevere, Andre (1999). "Composing the Other." In Susan bassnett and Harish Trivedi eds. Post-colonial Translation. Theory and Practice. London and New York: Routledge.

M a r s u d i (2003). Stylistic irony and banter within the rubric of 'Mr. Whip 'in the Jawa Pos newspaper. Kappa Special Edition of Social Science, 1-10. 2003.

McGraw-Hill Dictionary of American Idioms and Phrasal Verbs. (2002). The McGraw-Hill Companies, Inc.

Moentaha, Solihen. (2006). Language and Translation. Jakarta: Kesaint Blanc.

Mubarak, Zakky, Husmiaty Hashim, Ismala Goddess, Ari Harsono. (2008). Man, morals, manners and society. University of Indonesia.

Newmark, Peter. 1981). Approaches to Translation. New York: Pergamon. 
Newmark, Peter. (1988). A Textbook of Translation. Hertfordshire: Prentice Hall International

Nida, E.A. and Charles R. Taber. (1974). The Theory and Practice of Translation. Leiden: E.J. Brill.

Nord, Christiane (1997). Translation as a Purposeful Activity. UK: St. Jerome.

O'Grady, William, Michael Dobrovolsky, and Mark Aronoff. (1989). Contemporary Linguistics: An Introduction. New York: St. Martin's Press.

Podo, Hadi and Joseph J. Sullivan. (1998). Proficient in English. Phrase Dictionary Indonesia - English. Jakarta: PT. Gramedia Pustaka Utama.

Pollard, David (1998). "Introduction." In Translation and Creation: Readings of Western literature in Early Modern China, 1840-1918. Amsterdam: John Benjamins Publishing Company.

Language Center of the Ministry of Education. (2002). Indonesia Dictionary. Third Edition. Jakarta: Balai Pustaka.

Said, Mashadi. (2007). Assessing translation. Faculty of Literature. Gunadarma University Jakarta

Sastrio, Tri Budhi. (2008). Translation: Between Uncertainty and Doubt. Papers: National Seminar on Literary Translating and subtitling. Faculty of Languages and Literature, University of Dian Nuswantoro

Stevens, Alan M. and A. Ed. Schmidgall-Tellings. (2004). Complete Dictionary Indonesia - English. Ohio: Ohio University Press.

Suryawinata, Zuchridin and Sugeng Hariyanto. (2003). Translation. Discussion of theory and practical guide to translate. Jogyakarta: Doubleday.

The American Heritage Dictionary of theEnglish Language, Fourth Edition. 2000. Houghton Mifflin Company.

Tianmin, Jiang. (2009). Translation in context. Available in Translation journal (http://accurapid.com/journal) .

Toury, Gideon (1995). Descriptive Translation Studies and Beyond. Amsterdam and Philadelphia: Benjamins.

Venuti, Lawrence (1995). The Translator's Invisibility: A History of Translation. London: Routledge.

Venuti, Lawrence (1998). The Scandals of Translation: Towards an Ethics of Difference. London and New York: Routledge. 
Venuti, Lawrence. (2004). The Translation Studies Reader. New York: Routledge.

Zaidan, A.R. et al. (1994). Dictionary of Literary Terms. Balai Pustaka, Jakarta 